Jaume Coll Mariné - Grupa prevoditelja

\title{
Ova je tama, kažeš, put
}

\section{Krave}

Ako odjednom u daljini

gledaš daleko izvan kuće

i vidiš Planu, Pirineje

i tamo gore, sasvim sprijeda,

crkvu, a ona stoji sama,

sklopi tad oči, sve to sakrij,

vidjet ćeš Planu, Pirineje,

i ispred sebe, crkvu, samu

i krave što se tromo kreću

prođeš li kao da te motre

i kažu "a", a ti, "pa ide"

(pogneš glavu, rogove one);

a, telad, baš njih briga

tu im je sve, čak i sisanje

ništa da krene, ništa da svrši, 
vjetar je danas, pa i iznutra, i tako čitava života.

\section{Snijeg}

Nema ti više vremena

otopili prsti su snijeg

skriven duboko u dnu,

u dnu svakog ormara tvog.

Više ti vremena nema

kad vrijeme sam ja il drugi

- olinjalo pseto il psić

sretan na prsima tvojim

oblim od usta što s njih su

pile i život i smrt.

Snijeg će se topit pod prsima,

prstima, očima tvojim,

ispraćaš suzama škrtim

zbogom što mrsko ti zvuči

- sporo topi se snijeg i vrijeme

onkraj puta, onkraj noći; - 
i gledaš gdje vrijeme meko,

hladno, oblo i sivo toči.

Snijeg će se topit i bit će

ko tvoje jezerske oči

goleme, što vuku me dnu;

snijeg će se topit i bit će

ko tvoja mekana prsa

i žuto zaći će dani

u sate gluhi i stari:

dani grčki, tebi strani...

Nema ti vremena više,

s tvojih vjeđa topi se snijeg,

uzlaziš ko rijeka ušću,

ko riba iz usahla mora.

\section{Pjesma o špilji}

I vraćaš se, i vraćam se.

M. M. Marçal

Toliko njiše nas vjetar

i more, ako nas vidi, 
otvara neki se procijep

i govori uđi, idi.

Toliko noći je mjesec

na prozoru znao sjati,

od tvoga radosna smijeha

sve pršti, ne može stati.

Utroba tvoja je špilja,

kraja joj ne možeš znati.

Toliko laskanja tvoga

i laskanja moga dok sniš.

Toliku prešli smo stazu

što stazom teško je zvati.

Ako nam nestane ljestvi

kako se vratiti tada?

Otvore širom se vrata,

iz igre ispadam sada

- ako nam nestane ljestvi? -

pogledom gore me vrati. 
Utroba bješe ti špilja,

kraja joj ne možeš znati.

\section{Alba}

Roditi se od tebe

do svijeta svakog dana obnovljena.

M. M. Marçal

Ustajem, kao da spavaš,

vrtiš se, ali jedva

da kažeš ne, da sama

doći ćeš, al ti se ne da.

Uvlačiš se u plahte,

u njima tama je plava

Skrivaš se, tad sve zađe

I znaš da se ti udaljavaš.

Spavala bi, svjetlo gasim

iz kuće izlazimo nas dvoje,

ulicama idemo starim,

krivudavim, sve do zore. 


\section{Plavi konji}

U sedam uvečer stigoše pred vrata kuće,

golemi i tamni, a griva im bijela,

prođoše kraj pasa u tamnom svjetlu sutona

i uz lavež pasa pođoše dalje

ržući mirno, tamni, i pomalo

tu i tamo snažno mahali glavom,

snažno mahali repom, hodajuć sporo;

i vikao sam "ća!", idite odavle,

"ajte ća!", i otišli su gore, "gore!...",

i pognuše glave, i malo su pasli

i osvrnuv pogled odoše dalje,

ržući mirno i milujuć večer;

a noć ih odvodi kroz odraz večeri,

dok oni se osvrću, plavi i tamni,

golemi i tamni, a griva im plava

ržući mirno, a griva im plava,

svi osim jednoga, sporijeg, plavljeg i debljeg,

koji je gledao kako odlaze, 
koji je gledao kako odlazim, "ća!",

ržući mirno, gore, prema kući.

\section{Verdaguer}

Slušah slavuja kako pjeva u šumi,

i hodao sam i katkad ga čuh jače, a katkad slabije,

i kad mi se činilo da mi se približava i da je već nada mnom

i da samo trebam dignuti pogled da ga vidim

ili da pružim ruku da ga dohvatim, kad li stabla,

biljke, planine nabujahu

i sve bje čisto i blistaše jasnim i prirodnim svjetlom,

on na trenutak zašuti na kupini ili iznad

mladog javora i sve što vidjeh bje maleno;

i hodao sam dalje i ponovo ga začuh

ali iz veće daljine. Pratio sam pjesme

svakog dana i svake noći, i to sam činio

dugo vremena, dok nisam naučio neke,

ali loše otpjevane. Onda, kada sam odlazio iz šume,

i hodao ulicama nekih sela i gradova 
koje ne poznavah, izgovarah ih u sebi ili potiho

ili načinih nove, za kasnije. I samo se

povremeno vraćam u tu šumu,

da bih čuo kako se šuma obnavlja pjesmom

slavuja, a za jelo, ljeti

nekoliko kupina, onih slatkih i sjajnih.

\section{Listopadski prozor}

Iz visine i bez žurbe spušta se dan,

što mome životu nosi pomutnju,

što nosi pomutnju u šumu i zrak

i slijeće na hrašće, na brda i pse

i krovove šume ovoga jutra.

Iz visine dan se spušta i nije sam,

društvo mu mračno Montcadino jutro,

i nosi nam jutro od nekoć i sad,

i nosi nam jutro drevnije od kuće,

ovo jutro obnavlja se:

ovo jutro mračnih pleća kod Svete Eulalije, 
ovo jutro noć je bila što pada na Bellmunt,

ovo jutro sad se svlači, tijela nema,

i svjetlo je i sjaj je i zvuk je kiše,

ispunjeni dan što seže iz dubine,

što seže iz dubine sa zvukom noći;

mračan povik pasa noćnih,

što nosi pomutnju u šumu i zrak

mračan zvižduk ovog jutra.

(Jutro što broji ljeta trista u vrtu časa,

ptica što pjevajuć godine krije,

što spokojno leti u visini, sama,

ptica što pjevaše čitava jutra.

Jesenji konci što sada me stežu,

čvrsto sam ušit u tijelo planine,

i medvjed je moćno oko planine:

bit lađar će mrtvih u ovoj noći.

Pjesme od mrvica što sada ječe,

ko korak neučinjen, ko kakav vrt;

život proveden skrito iza stakla. 
Što živjeli nismo sve na klupi piše:

Vilavendrell na crkvenoj klupi piše.

Što biti smo mogli, tek malo jesmo,

što biti smo mogli, a više nismo

u kući se krije i slovima tamnim

zapisano sve je u tamnome drvu jutra.)

Iz visine, iz visine spušta se dan

pada i ustaje tu pred ovom kućom,

pred prozorom moje sobe, ovdje gdje sam,

što otvoren stoji, što uvijek čeka

poput bika premorena bez krda i snage

što skriven u kutu gleda gore, prema domu.

\section{Kokoti}

Is an act not of violence but of law

Ted Hughes

Tu su, crvenkasti i širokih prsiju,

crvenkasti, na okupu kad prilazimo

kriču jer dolazimo i šire krila, 
dižu glavu, crvenkasti i nakostrušeni.

"Preveć su narasli." Odlaze u kut;

zatvaramo vrata, mirno, i gledamo in.

Biramo jednoga, najdebljeg ili najsporijeg;

približavamo se da bi ga zgrabili, motreći ih revno otvorenih očiju,

poput velike lisice što se zasitila

I ne treba joj, jer je već našla, te pazi,

onog šepavog da bježi ali ne može.

Gotovo nikad ne pjevaju, samo čekaju,

njihov je pjev za dana uvijek slabašan.

Drhte, sasvim prazni, od gladi i žeđi;

noćnici su. Ali ništa, to je to.

Ispružen, pritisnutih krila i nožica,

predaje se, smiren, ne odupire se.

Teško puše, i krv teče

po mramoru, i curi, crvena, u posudu.

Samo rez, ništa više, i on je stvar:

komad svježeg mesa, mekanog i žutog, 
koji treba očistiti. Poput zakona,

život dobro spravljen za smrt.

\section{Sveti Frane i ptice}

Krotki su ti nalik

Carles Riba

Neke su ptice sletjele preda nj,

i mnoge druge ptice sletjele su preda nj,

a on, iznuren mnogim mislima i sumnjama,

zastao je sred tog polja, gledao in

i govorio im, i došlo je još ptica

sa stabala i drugih mjesta, i prilazila su

sva stabla, biljke - stabla zelena

i žuta - i mnoge druge životinje slušale su ga

i gledale, i sve bijaše u svjetlu, "pjevajte rijeke,

izvore, doline i planine, polja u kojima živite",

a ni svjetlo ni zrak ne bijahu teški, sve bijaše lagano,

jasnije, a iznad svega bijahu golema stabla

i lijepo uređene kuće koje stadoše rasti, i one progovoriše, 
i svi su ih razumjeli. A tada Frane, sam,

nakon što otpusti ptice i pogledom ih isprati

na zapad, na istok, na jug i na sjever,

ne mogavši više izustiti ni riječi, lagan raširi krila,

ustade i, pjevajući, nestade duboko u šumi,

nestade među pticama koje su ga čekale,

onako smeđe, u letu prema sutonu.

\section{Posjeta}

Bilo je vrlo hladno i psi su nas gledali

iz svojih skloništa od kamena i drva, skutreno

pratili kako pada vrijeme, nekako brzo

i sporo u isti čas, sve narančasto

zbog narančasta svjetla u pet. Bilo je vrlo hladno

i stajali smo pred kućom, ne radeći baš ništa,

a zima se povlačila u mrak iza stabala,

niz polja i vanjske zidove kuće; i tad me

pogleda mačka i reče, "Vrlo je hladno,

znam, ali hladnoća je dobra jer bregove steže 
i široka im pleća i staze i utrobu česmine;

i ova hladnoća opet postat će vlaga kad otopi se

s dolaskom proljeća, kad obnovi se, kad je najljepše vrijeme,

uz blatnjavu pjesmu jutra, i tako je sa svime,

pogledaj hrast ili klen, pogledaj šljivu,

čine se mrtvi, i napola su umrli

dobrom smrću, možda, no čuvaju tamu i čuvaju svjetlo;

spavaju, i ta smrt bit će zelena i bit će slatka,

poput proljetnog jutra. I vidiš onu šumu i one planine?,

sve je tamo moje jer tako sam tražila i tako mi je dano,

i bila sam zemlja i bila sam izvor, i bila sam to sama,

tako da me ne vide; i kupala sam se i bila sam jeleni i bila sam noć.

Ostavila sam vam mlada zeca; ulovila sam ga za vas.

A sad idem, moram poći, i možda je kasno, znam,

putem koji vodi do pojilišta; i ondje će možda biti lisica

ili, još dalje, netko će me odnijeti, a tamo kamo me odvedu

bit će dom, i ja ću njima biti dom,

onako kako su me psi i zidovi i ovaj vjetar udomili." 
I dugo sam gledao kako odlazi;

i posve se smrklo i psi su lajali,

u sebe sigurni, možda sat, a možda i dva.

\section{O jednoj pjesmi iz 2006.}

U gluhu ponoć on po kući skita,

prsti mu oči, sve hodajuć pipa:

zidove, vrata i pradavnu tminu,

tminu što pred njim polako se kida.

U gluhu ponoć, dječak tamno diše

sve ono dosad njemu ne da mira,

bosonog on sluša vjetar što víja

i uspravno kroči jer noge vide

gdje drveni pod u kamen se sliva,

pod čudnim snijegom kamen što se skriva.

A o životu dal itko mi priča?

Smrknuto dječak bez veselja kroči

i olujnim putem odluči poći,

put dana, noći i snijega što sada 
odavna stoji i još uvijek pada.

U gluhu ponoć, uz jeku zvonika,

korak je dječaka što put šume hita

sve manje korak, sve više planina,

što uvijek se spušta, sve daljom biva,

i postat bi htjela gordi vrhunac;

što sad se diže, a jedva je išta:

iz vremena trula, sama je kora,

ni nalik rijeci, tek obala mokra.

A dječak se vraća dok sviće zora,

i otvara oči na pragu kuće

i znade da mi smo oči te kuće,

i znamo za divlje njegovo srce,

za šumu u njemu, noge od mora,

kaže da ovaj dan noć je iz tora,

a on noć vidje, tu plažu iz snova.

\section{Prijateljici}


(Boscalt)

Na neznanom mjestu.

\&nbsp;\&nbsp;\&nbsp;\&nbsp;\&nbsp;\&nbsp;\&nbsp;\&nbsp;\&nbsp;\&nbsp;\&nbsp;\&nbsp;\&nbsp;\&nbsp;\&nbsp;\&nbs M. M. Marçal

Krenusmo ti i ja putem što nismo ga znali;

\&nbsp;\&nbsp;\&nbsp;\&nbsp;\&nbsp;na mjesto što ga ne znasmo, krenusmo ti i ja.

Krenusmo ti i ja, s omotom bora i dana,

\&nbsp;\&nbsp;\&nbsp;\&nbsp;\&nbsp;s omotom noći, krenusmo ti i ja.

Krenusmo ti i ja, doli su tamo i kuće,

\&nbsp;\&nbsp;\&nbsp;\&nbsp;\&nbsp;ti okrenu se reć mi to, krenusmo ti i ja.

Krenusmo ti i ja, nalet sunca nas tjera,

\&nbsp;\&nbsp;\&nbsp;\&nbsp;\&nbsp;vjetar puhaše blago, krenusmo ti i ja.

Krenusmo ti i ja, i uspesmo se u podne,

\&nbsp;\&nbsp;\&nbsp;\&nbsp;\&nbsp;nad šumom nad danom, krenusmo ti i ja.

Krenusmo ti i ja, gore bi odmah sve jasno,

\&nbsp;\&nbsp;\&nbsp;\&nbsp;\&nbsp;penjući se dalje, krenusmo ti i ja.

Krenusmo ti i ja, dublje u mračnu tu šumu,

\&nbsp;\&nbsp;\&nbsp;\&nbsp;\&nbsp;u šutnji ti vodeći nas, krenusmo ti i ja.

\section{Tri proze}




\section{Misaelu Alermu}

U cik zore, kada se prođu Sobrebosc i Teieda, vidi se kako izlazi tekst, sjajan i velikih ruku, koji crtamo ili pišemo, koji hoda i vidi nas gdje dolazimo.

No, kada se smrači, diže se i sve nam obavije; i kreće se među stablima, ne bi li mu pokazao puteve i mjesta na kojima se krije.

Víctoru Sunyolu

Most je, ili ne, tek prijelaz, da, prijelaz, koji postavljaš jer želiš preko rijeke, pa uzimaš trupce i brezovu koru i nešto kamenja i odjednom to više nisu trupci ni brezova kora ni kamenje: to je most, ili ne, tek prijelaz, da, prijelaz.

Postavio si ga da bio prešao preko i da zatim padne; no ispada da si prešao rijeku i da si na istoj strani kao i prije pa sad tražiš još trupaca i breza i kamenja...

\section{[FRAGMENT]}

Joanu Ferreru Gràciji

Kada spusti se Noć, stvari se približavaju i nalikuju jedna drugoj; no, kada svane Dan, malo pomalo, nalikujući jedna drugoj, odvajaju se, kao stabla od zemlje ili riječi od tijela.

\section{Triolet}

\section{Za Mariliin Vassenin}

Ova je tama, kažeš, put

tim putem nama je poći;

ko sve što nas tjera u kut,

ova je tama, kažeš, put.

Brige su stigle u tvoj vrt, 
brige što čuvaš i noći;

ova je tama, kažeš, put

tim putem nama je poći.

\section{(ब) $\Theta \Theta$}

Creative Commons Attribution-NonCommercial-NoDerivatives 4.0 International License 